\title{
Histological structure of the digestive tract and digestive enzymatic activity of juvenile Pacific seahorse (Hippocampus ingens)
}

\author{
Daniela Corona-Rojas ${ }^{1}$, Renato Peña ${ }^{1}\left(\mathbb{D}\right.$, Carmen Rodríguez-Jaramillo ${ }^{2}$ \\ Dariel Tovar-Ramírez ${ }^{3}$ (D) \& Patricia Hinojosa-Baltazar ${ }^{3}$ \\ ${ }^{1}$ Instituto Politécnico Nacional, Centro Interdisciplinario de Ciencias Marinas \\ Unidad Piloto de Maricultivos, La Paz, B.C.S., México \\ ${ }^{2}$ Laboratorio de Histología e Histoquímica, Centro de Investigaciones Biológicas del Noroeste S.C. \\ La Paz, B.C.S., México \\ ${ }^{3}$ Laboratorio de Fisiología Comparada y Genómica Funcional, Centro de Investigaciones \\ Biológicas del Noroeste, S.C., La Paz, B.C.S., México \\ Corresponding author: Renato Peña (rpenam@ipn.mx)
}

\begin{abstract}
The histological structure, histochemical features, and enzymatic activity of the digestive tract of juvenile Pacific seahorse (Hippocampus ingens) are described to provide information during the cultivation of this species. Serial histological sections were stained with either hematoxylin-eosin, alcian blue-PAS, toluidine blue, Sudan black, Masson's trichome, and ninhydrin-Schiff to describe the general features and the presence of glycogen, mucopolysaccharides, lipids, muscle layers, and proteins, respectively. The enterocytes height and the mucosal villi height in the esophagus and intestines were measured. Additionally, the digestive enzymes trypsin, chymotrypsin, lipase, amylase, aminopeptidase, acid phosphatase, and alkaline phosphatase activities were recorded. The esophagus showed two distinctive regions, the anterior with numerous mucous cells secreting acid mucins and the posterior with longitudinal folds and no mucous cells. The intestine was differentiated into three regions. The anterior showed goblet cells secreting acid and neutral mucins, while the middle and posterior regions presented goblet cells secreting only acid mucins. The activity of aminopeptidase, chymotrypsin, and amylase showed low levels, while the trypsin and acid phosphatase activity levels were intermediate. Lipase and alkaline phosphatase showed the highest activities. The results point that juvenile $H$. ingens presents a digestive structure similar to other teleost species. The high levels of lipase suggest that juvenile $H$. ingens have high requirements for lipids during this stage.
\end{abstract}

Keywords: Hippocampus ingens; Pacific seahorse; digestive tract; histological structure; enzymatic activity

\section{INTRODUCTION}

The Pacific seahorse (Hippocampus ingens) lives in shallow tropical waters and has been reported from San Diego, California, to northern Peru, including the Gulf of California and the Galapagos Islands (Lourie et al. 2004). Currently, wild populations of seahorses are overexploited worldwide for their use in traditional Chinese and European medicine, human food consumption, ornamental use, and by-catch in shrimp fisheries (Foster \& Vincent 2004). Therefore, H. ingens is classified as a vulnerable species by the IUCN
(International Union for the Conservation of Nature) and in Mexico is listed as a species subject to special protection (NOM-059-SEMARNAT-2010).

The culture of seahorses is considered an alternative to satisfy their increasing demand and reduce overexploitation. However, the scarcity of information on biology and reproduction in most seahorse species, particularly $H$. ingens, hinders the development of an adequate culture protocol. Additionally, the limited knowledge of their nutritional requirements and digestive morphology and physiology during juvenile stages have been identified as a major obstacle to their com-

Corresponding editor: Fernando Vega 
mercial success (Koldewey \& Martin-Smith 2010, Otero-Ferrer 2011, Novelli et al. 2016).

The digestive tract of teleost fishes varies in morphology and structure according to taxonomy and feeding habits (Al-Abdulhadi 2005). However, the general organization of the digestive system in vertebrates remains relatively constant, consisting of an oral cavity (buccopharynx), esophagus, stomach, intestine, rectum, liver, and pancreas. The digestive tract in the genus Hippocampus sp. has been studied, and the absence of teeth, tongue in the buccopharynx as well as the absence of the stomach are common features (Wardley 2006, Palma et al. 2014, Corona-Rojas 2015, Novelli et al. 2015, Ofelio et al. 2018). Some studies reported the activity of digestive enzymes ontogeny in the early development of seahorses, and the proteolytic activity relies mainly on pancreatic proteases like trypsin and chymotrypsin. The activity of other digestive enzymes like amylase and lipase has also been reported (Wardley 2006, Blanco et al. 2016, Novelli et al. 2016, Segade et al. 2016). However, the digestive tract structure and digestive enzymatic activity in juvenile $H$. ingens have not been reported. Therefore, the objective of the present study was to describe the histological structure and some histochemical characteristics of the digestive tract and reveal the presence of digestive enzymes in juvenile $H$. ingens. This information will allow us to gain more knowledge related to digestive physiology and nutritional requirements to improve the culture of this species.

\section{MATERIALS AND METHODS}

Fifteen three-month-old Hippocampus ingens juveniles of $56.95 \pm 3.43 \mathrm{~mm}$ (mean \pm standard deviation) and $0.43 \pm 0.06 \mathrm{~g}$; length and weight respectively, were donated from the production farm "INGENS Cultivos Marinos" in Mazatlán, Sinaloa, Mexico. They were cultured at an average water temperature of $24 \pm 0.4^{\circ} \mathrm{C}$, salinity 34 , natural photoperiod, and fed ad libitum with metanauplii and juvenile Artemia until the day before they were donated.

Upon arrival to the Unidad Piloto de Maricultivos (UPIMA) of Centro Interdisciplinario de Ciencias Marinas of the Instituto Politécnico Nacional (CICIMAR-IPN), the specimens were euthanized by overexposure in a phenoxyethanol solution. The digestive tract from 10 specimens was removed and pooled in a $2 \mathrm{~mL}$ Eppendorf tube and kept in an ultrafreezer at $-80^{\circ} \mathrm{C}$ until the analysis of the digestive enzymatic activity. Five juveniles were fixed in Davidson's solution for further histological analysis.
According to the principles in good laboratory animal care, the transport protocols and sampling procedures reported in this study followed the Official Mexican Standard NOM-033-SAG/ZOO-2014 "Methods for killing domestics and wild animals".

\section{Histological and histochemical analysis}

The specimens were dehydrated in a graded series of ethanol in a tissue processor (Leica ASP200 S) and rinsed with Xylol. Once dehydrated, they were included in paraplast blocks, and serial sagittal sections $(4 \mu \mathrm{m}$ thick) were cut with a rotatory microtome (Leica RM 2155). The tissue sections were stained with different techniques to describe the different histological and histochemical features of the digestive tract (Pearse 1985): hematoxylin-eosin (Harris) to describe the general histological structure; alcian blue-periodic acid-Schiff (PAS) to detect the presence of glycogen, acid, and neutral mucopolysaccharides; toluidine blue was used to differentiate neutral mucopolysaccharides; Sudan black to stain triglycerides and lipids, as well as lipoproteins; Masson's trichrome for muscle layers and collagen fibers; and ninhydrin-Schiff for proteins.

Several cellular characteristics were measured in the histological sections of every esophagus and intestine segment: enterocytes height (from the basal membrane to the apical region, including the microvilli) and height of villi (from the base of the mucosa layer to the top of the villi, including the enterocytes). After staining, the sections were observed with an optical microscope (Olympus BX41). Digital photographs were taken using a digital camera (Nikon DS-Ri1) and analyzed with Image Pro-Plus software v.9.

For image analysis, in every segment of the digestive tract, a minimum of 20 histological sections was observed. For evaluating the enterocyte's height, 1410 and 3120 measurements were made in the esophagus and the intestine, respectively. In the villi height, 356 and 1375, measurements were made in the esophagus and the intestine, respectively.

\section{Enzymatic analysis}

The intestines and accessory organs (liver and pancreas) were homogenized in a single vial with milli$\mathrm{Q}$ water and different size glass beads in a sample homogenizer (FastPrep-24TM 5G) at $4 \mathrm{~m} \mathrm{~s}^{-1}$ for $40 \mathrm{~s}$ to prepare the enzymatic extract. The extract was centrifuged (Eppendorf $5430 \mathrm{R}$ ) at 17,949 $\mathrm{g}$ for $10 \mathrm{~min}$ at $5^{\circ} \mathrm{C}$, and the supernatant was stored in $1.5 \mathrm{~mL}$ aliquots at $-80^{\circ} \mathrm{C}$ for later use. The protein concentration was determined following Bradford (1976), and the calibration curve was carried out from a standard solution of bovine albumin $\left(0-0.5 \mathrm{mg} \mathrm{mL}^{-1}\right)$. 
The activity of the digestive enzymes trypsin (EC 3.4.21.4), chymotrypsin (EC 3.4.21.1), $\alpha$-amylase (EC 3.2.1.1), lipase (EC 3.1.1.3), acid phosphatase (EC 3.1.3.2), and alkaline phosphatase (EC 3.1.3.1) was evaluated using fluorometric techniques. The aminopeptidase (EC 3.4. 11.1) activity was detected using the spectrophotometric method. Trypsin activity was assessed according to the method reported by Toledo-Cuevas et al. (2011), using $6 \mathrm{mM}$ of Boc-GlnAla-Arg-7 amido-4 methyl coumarin hydrochloride (Sigma B4153) at $\mathrm{pH} 7.4$ as a substrate. The chymotrypsin activity was determined following the method reported by Rotllant et al. (2008), with $6 \mathrm{mM}$ of N-succinyl-Ala-Ala-Pro-Phe-7 amido-4 methyl coumarin (Sigma S9761) at pH 7.4 as a substrate. The $\alpha$-amylase activity was assayed following VegaVillasante et al. (1993) using $50 \mathrm{mmol} \mathrm{L}^{-1}$ Tris- $\mathrm{HCl}$ buffer (pH 7.5) and soluble starch (1\%) as substrate. The incubation period lasted five min at $25^{\circ} \mathrm{C}$. Sodium carbonate $(2 \mathrm{~N})$ and dinitro salicylic acid reactive was added to reveal the reaction mechanism. The reaction was stopped by boiling it for $15 \mathrm{~min}$. One unit of enzyme activity was defined as the amount of enzyme required to increase the optical density of 0.01 units per minute at $550 \mathrm{~nm}$. The lipase activity was determined with the method reported by Toledo-Cuevas et al. (2011), using $50 \mathrm{mM}$ of 4 methylumbeliferol butyrates (MUB) at $\mathrm{pH} 8.0$ as a substrate. The activity of acid and alkaline phosphatases was determined using ToledoCuevas et al. (2011) using 6,8-difluoro-4-methylumbelliferyl phosphate (DiFMUP) as substrate and sodium acetate $0.5 \mathrm{M}$ at $\mathrm{pH} 5.0$ as a buffer for acid phosphatase. For alkaline phosphatase, $100 \mathrm{mM}$ of glycine with $1 \mathrm{mM}$ of $\mathrm{MgCl} 2$ and $1 \mathrm{mM}$ of $\mathrm{ZnCl} 2$ at $\mathrm{pH}$ 10.4 was used as a buffer. The aminopeptidase activity was determined using Maraux et al. (1973) method, with $0.1 \mathrm{M}$ L-leucine p-nitroanilide at $\mathrm{pH} 7.0$ as a substrate. The molar extinction coefficient of the substrate was $8200 \mathrm{~L} \mathrm{~mol}^{-1} \mathrm{~cm}^{-1}$ at $410 \mathrm{~nm}$. All the enzymatic activities were expressed as total activity (U $\left.\mu \mathrm{L}^{-1}\right)$ and specific activity ( $\mathrm{U}$ m protein ${ }^{-1}$ ) according to Corona-Rojas (2018).

\section{Statistical analysis}

The normality of the data was verified with the Kolmogorov-Smirnov test, while the homogeneity of variance was determined using Levene's test. Results were transformed to $\log 10$ before the ANOVA, but the means and standard error of untransformed data are reported. One-way ANOVA was applied to compare the enterocytes' height and the height of the villi in the esophagus and intestine. A Tukey post-hoc test was applied to identify the interactions between the treatments. The level of significance was $P<0.05$.
StatisticaTM v.12 software was used for the statistical analysis of the data.

\section{RESULTS}

The digestive tract of Hippocampus ingens was divided into the esophagus, intestine, and accessory glands (liver and pancreas). The intestine was arranged in several folds; the liver surrounded the anterior intestine while the pancreas was diffused around the intestine and liver. Histologically, the digestive tract is composed of four main layers arranged concentrically from the inside out into the mucosa layer lined with epithelial cells, the submucosa layer consisting of connective tissue and blood vessels, the muscular layer formed by muscle fibers of the smooth or striated type and the adventitia layer composed of connective tissue. Several structural differences between the digestive tract segments were observed, which allowed the identification of different segments in the esophagus and the intestine (Fig. 1).

\section{Esophagus}

Based on its general structure, two regions were distinguished in the esophagus: the anterior and the posterior. In the anterior esophagus, the mucosa layer was composed of columnar epithelium with numerous goblet cells (Figs. 2a,c,d) with a positive reaction for alcian blue-PAS presence of acid mucins (Fig. 2d). The submucosa layer comprises connective tissue and blood vessels, and the muscular layer was formed by striated muscular fibers (Fig. 2c). In the posterior esophagus, the muscular layer presented skeletal striated muscle surrounded by connective tissue, also known as perimysium (Fig. 2b) The mucosa layer was composed of columnar epithelium, and no goblet cells were obser-

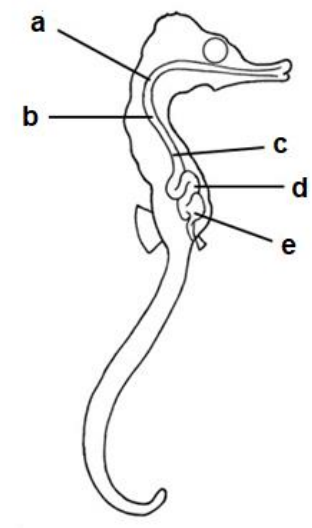

Figure 1. General scheme of the digestive tract in juvenile Pacific seahorse Hippocampus ingens, showing the a) anterior esophagus, b) posterior esophagus, c) anterior intestine, d) medium intestine, d) posterior intestine. 


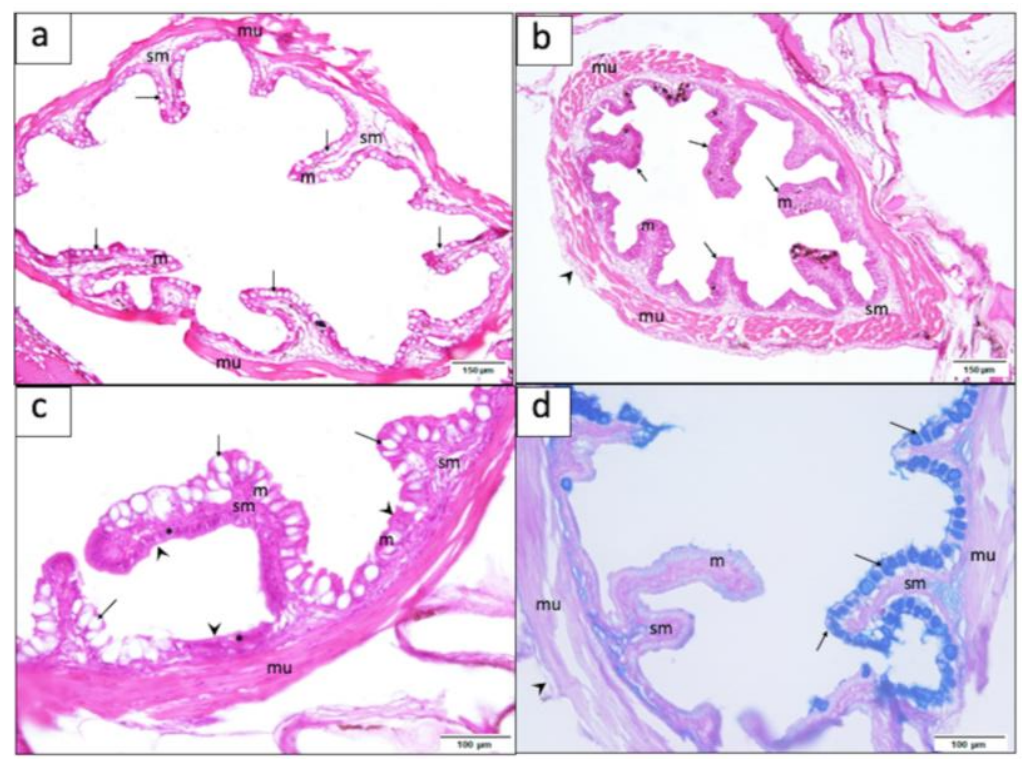

Figure 2. Transverse sections of the a-b) anterior and c-d) posterior esophagus of juvenile Pacific seahorse Hippocampus ingens. a) Anterior esophagus with the presence of goblet cells (arrows) in the mucosa layer. hematoxylin-eosin; b) posterior esophagus without goblet cells in the mucosa layer (arrows). The arrowhead signals the perimysium. hematoxylin-eosin; c) The mucosa layer in the anterior esophagus is composed of goblet cells (arrows). The arrowhead signal the microvilli and the asterisks the nucleus of the epithelial cells. hematoxylin-eosin; d) anterior (right) and posterior (left) mucosa of the esophagus. No goblet cells are located in the posterior region. The arrows indicate the goblet cells in the anterior region positively stained. Alcian blue-PAS. m: mucosa layer, sm: submucosa layer, mu: muscular layer.

ved (Fig. 2d). The outermost layer was the adventitia consisting of loose connective tissue (Fig. 2d). The epithelial cells were significantly taller (13.29 \pm 0.09 $\mu \mathrm{m})$ in the anterior esophagus when compared with the ones of the posterior esophagus $(11.03 \pm 0.13 \mu \mathrm{m})$. Likewise, the height of the villi in the anterior esophagus showed significantly $(P<0.05)$ higher values $(123.39 \pm 1.74 \mu \mathrm{m})$ compared to the posterior esophagus $(91.85 \pm 2.47 \mu \mathrm{m})$.

\section{Intestine}

Based on the histological features of the mucosa layer like the mucous secretion by the goblet cells, the size and form of the villi, and the height of the enterocytes, three intestinal regions were distinguished: anterior, middle, and posterior. The mucosa layer in all the intestinal regions showed the same arrangement, being lined with simple columnar epithelium with a welldeveloped brush border. The submucosa and muscular layers of these three segments had the same structure: the former was composed of a dense layer of connective tissue with blood vessels, while the latter was formed by a thick layer of smooth muscle fibers.

The anterior intestine had a mucosa with mucous cells positively stained with alcian blue-PAS denoting the secretion of acid and neutral mucopolysaccharides (Fig. 3a). The presence of supranuclear vacuoles in the apical part of the enterocytes stained with Sudan black exposed the existence of triglycerides (Fig. 3b).

The middle intestine showed numerous goblet cells of the acidic type positively stained with alcian bluePAS (Fig. 3c). The villi in the middle intestine were larger and thinner than those of two other regions of the intestine (Fig. 3d).

In the posterior region of the intestine, goblet cells with a mucous acid secretion positively stained blue with alcian blue-PAS were also present (Fig. 3e). Villi in the posterior intestine were present in fewer numbers than in the other intestinal sections. The muscular layer in the posterior region was the thickest of the three intestinal regions (Fig. 3f). The histological measurements in the three intestine regions are presented in Table 1. The highest villi were observed in the middle intestine $(100.88 \pm 1.33 \mu \mathrm{m})$, and the mucosa of the posterior intestine showed the highest values of the enterocytes height $(13.49 \pm 0.07 \mu \mathrm{m})($ Table 1$)$.

\section{Enzymatic activity}

The specific and total enzymatic activities are shown in Table 2. Alkaline and acid phosphatases and lipase showed the highest specific and total activities, while aminopeptidase and chymotrypsin showed the lowest (Table 2). 


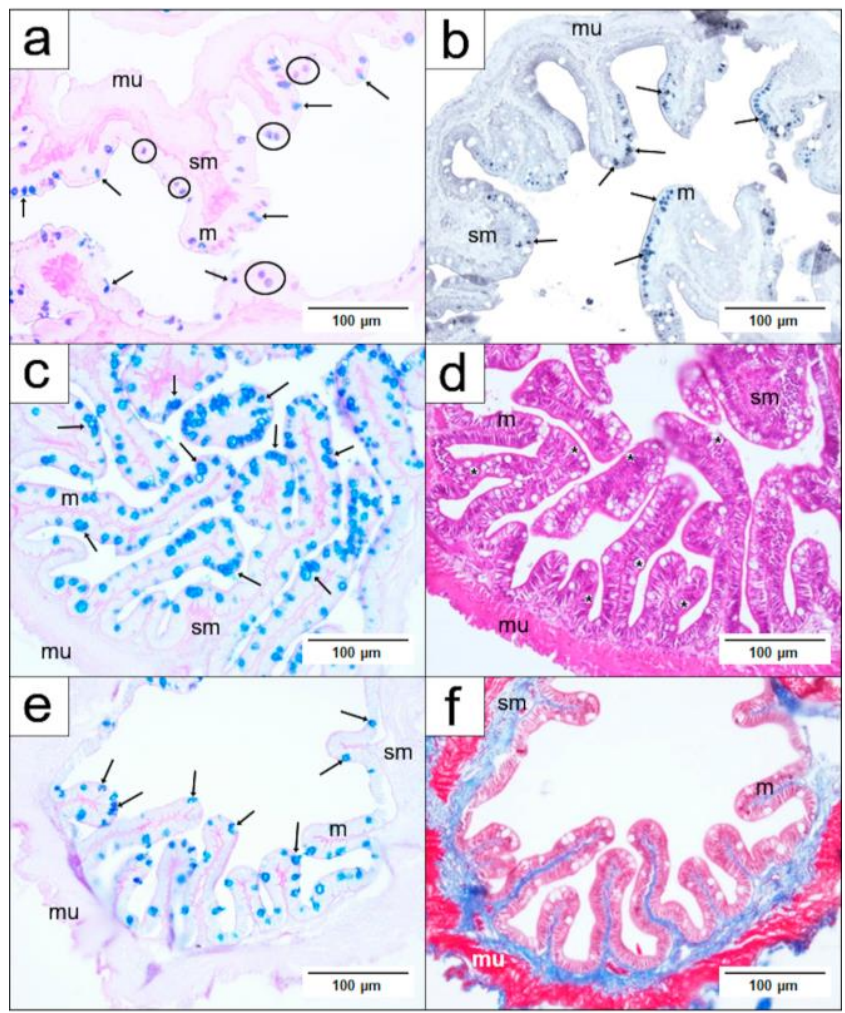

Figure 3. Transverse sections of the $\mathrm{a}-\mathrm{b}$ ) anterior, $\mathrm{c}-\mathrm{d}$ ) medium and e-f) posterior intestine of juvenile Hippocampus ingens. a) Presence of goblet cells in the mucosa layer stained with Alcian Blue-PAS denoting the secretion of acid (arrows) and neutral (circle) mucins, b) vacuoles positive for Sudan Black in the supranuclear region of the enterocytes (arrows), denoting the presence of triglycerides, c) goblet cells with an acidic-type secretion positively stained with Alcian Blue-PAS (arrows), d) intestinal villi, larger and slightly thinner than the other regions of the intestine (hematoxylin-eosin, Harris), note the presence of goblet cells with a negative reaction to H-E (asterisks), e) goblet cells (arrows) in the posterior intestine with an acidic mucous secretion positively stained to Alcian Blue-PAS, f) structure of the posterior intestine (Masson's Trichrome) with smaller and fewer villi and few goblet cells. m: mucosa layer, sm: submucosa layer, mu: muscular layer.

Table 1. Enterocytes height and villi height in the anterior, middle, and posterior regions of the intestine (mean \pm standard error) ( $\mathrm{n}=5132$ and 1732, respectively) of juvenile Hippocampus ingens. Different superscript denotes significant differences between intestinal segments at $P<0.05$.

\begin{tabular}{lcc}
\hline Intestinal segment & Enterocytes height $(\mu \mathrm{m})$ & Villi height $(\mu \mathrm{m})$ \\
\hline Anterior & $12.6 \pm 0.09^{\mathrm{b}}$ & $94.0 \pm 0.9^{\mathrm{b}}$ \\
Middle & $12.6 \pm 0.07^{\mathrm{b}}$ & $100.8 \pm 1.3^{\mathrm{a}}$ \\
Posterior & $13.4 \pm 0.7^{\mathrm{a}}$ & $98.9 \pm 1.0^{\mathrm{a}}$ \\
\hline
\end{tabular}

\section{DISCUSSION}

The histological structure of the intestine of Hippocampus ingens resembles the one described in many other agastric teleosts, including other seahorses like the big-belly seahorse $H$. abdominalis (Wardley 2006), the long-snouted seahorse H. guttulatus (Palma et al. 2014), and the long snout seahorse $H$. reidi (Novelli et al. 2015). The general pattern of four tissue layers in the digestive tract is present in $H$. ingens. However, some differences were detected among regions that distinguished two regions in the esophagus and three regions in the intestine. The absence of stomach in $H$. ingens is a common feature in other seahorses (Wardley 2006, Palma et al. 2014, Novelli et al. 2015, Segade et al. 2016) and some teleost species as well (Logothetis et al. 2001, Horn et al. 2006, Wilson \& Castro 2011).

Unlike other species where the stratified epithelium in the esophagus protects it against mechanical abrasions, and the invasion of microorganisms as food enters the digestive tract (Vieira-Lopes et al. 2013, 
Table 2. Total and specific enzymatic activity (mean \pm standard deviation) of juvenile Hippocampus ingens.

\begin{tabular}{|c|c|c|}
\hline Enzyme & $\begin{array}{c}\text { Total activity } \\
\left(\mathrm{U} \mu \mathrm{L}^{-1}\right)\end{array}$ & $\begin{array}{l}\text { Specific activity } \\
\left(\mathrm{U} \mathrm{mg} \mathrm{protein}^{-1}\right)\end{array}$ \\
\hline \multicolumn{3}{|l|}{ Proteases: } \\
\hline Aminopeptidase & $6.2 \pm 0.2$ & $1.4 \pm 0.05$ \\
\hline Chymotrypsin & $20.6 \pm 2.1$ & $4.7 \pm 0.5$ \\
\hline Trypsin & $261.2 \pm 20.2$ & $59.5 \pm 4.6$ \\
\hline Amylase & $39.3 \pm 5.5$ & $0.001 \pm 0.01$ \\
\hline Lipase & $1791.0 \pm 152.6$ & $408.2 \pm 34.8$ \\
\hline \multicolumn{3}{|l|}{ Phosphatases: } \\
\hline Acid phosphatase & $1074.5 \pm 84.0$ & $244.9 \pm 19.1$ \\
\hline Alkaline phosphatase & $2115.1 \pm 104.1$ & $482.1 \pm 23.7$ \\
\hline
\end{tabular}

Dos-Santos et al. 2015), in $H$. ingens, only villi lined with simple columnar epithelium is present. The villi of the anterior esophagus of $H$. ingens are taller and visually thinner than in the posterior region; the posterior esophagus is narrow, and the villi are short. A similar structure of the esophagus has been reported in the large yellow croaker Pseudosciaena crocea (Mai et al. 2005), the common dentex Dentex dentex (Carrassón et al. 2006), and the Antalya minnow Pseudophoxinus antalyae (Çinar \& Şenol 2006). However, in the western tubenose goby, Proterorhinus semilunaris, an inverse pattern was reported (Wołczuk et al. 2014). Only the anterior esophagus of $H$. ingens shows a large number of goblet cells secreting glycoproteins, which have been reported in other fish species (Gómez-Ramírez et al. 2010, Cohen et al. 2013, Guzmán-Beltran et al. 2013, Nazlić et al. 2014, DosSantos et al. 2015). The posterior esophagus has a greater muscle layer. This arrangement in the esophagus implies that the anterior esophagus functions as a food lubricant due to the presence of goblet cells and also as the first barrier against bacteria due to the immune function reported of the mucus secreted by these cells (Nazlić et al. 2014, Cardoso et al. 2015) while the posterior esophagus functions as a food transporter to the intestine with the large muscular area present covering the functions of an esophageal sphincter (Mai et al. 2005, Zhang et al. 2016).

Three intestinal regions were distinguished in $H$. ingens; anterior, middle, and posterior. The presence of villi and goblet cells is a typical intestinal feature increasing the number of enterocytes and, consequently, the absorptive area. In $H$. ingens, the villi are larger in the middle and posterior regions than in the anterior region. In other teleost species, the largest intestinal villi are reported in the anterior region as an adaptation to increase the absorption surface (Zambonino-Infante et al. 2008, Gómez-Ramírez et al. 2010). According to the intestinal region, the presence of goblet cells along the intestine of $H$. ingens varies in terms of proportion and type of secretion (Neuhaus et al. 2007). In the anterior region, goblet cells are abundant with acidic and neutral secretions (mucopolysaccharides). In the middle and posterior regions, only goblet cells with the secretion of acid mucins (acid mucopolysaccharides) are present. In most fishes, goblet cells with the secretion of the neutral type are reported in the anterior region of the intestine. In contrast, goblet cells with acid-type mucins are observed in the posterior region (Ribeiro et al. 1999, Carrassón et al. 2006, Banan-Khojasteh et al. 2009, Cohen et al. 2013, Hernández et al. 2014, Teles et al. 2017). The neutral mucins and the alkaline phosphatase activity act together in the digestion and absorption in the intestinal mucosa (Murray et al. 1996, Sarasquete et al. 2001). At the same time, the presence of acid mucins in the intestine has been associated with different functions (Gisbert et al. 2013). A physical barrier against abrasion and lubricant during food transit by the intestinal peristalsis (Gisbert et al. 2013). They have also been associated with the osmotic regulation in seawater teleosts (Domeneghini et al. 1998). The presence of sialic acid in the acid mucins has been associated with the protection against viruses and bacteria by preventing the recognition of their receptors in the intestinal mucosa (Gisbert et al. 2004, Nazlić et al. 2014). In the posterior intestine, the acid mucins have been related to the evacuation process (Shi et al. 2007), while the neutral mucins are responsible for neutralizing $\mathrm{pH}$ and protecting the intestinal mucosa (Manjakasy et al. 2009).

The presence of supranuclear vacuoles positively stained with Sudan black in the enterocytes of the anterior intestine of $H$. ingens denotes lipid absorption and a mechanism of temporary storage of lipids in the enterocytes, which have also been reported in larval and juvenile teleosts (Sarasquete et al. 1995, Wegner et al. 2009, Yang et al. 2010). However, some authors have 
considered lipid vacuoles in the enterocytes of the anterior intestine as a deficiency of lipid transport in the early developmental stages of fishes (Mai et al. 2005, Chen et al. 2006). The muscle thickness in the anterior intestine of $H$. ingens suggests weaker peristaltic movements and a longer time in the passage of food (Gómez-Ramírez et al. 2010) since the posterior intestine presented greater muscle thickness than the middle and the anterior regions.

In $H$. ingens, the proteolytic activity relies mainly on alkaline proteases due to the lack of a stomach and the acid proteolysis by the presence of $\mathrm{HCl}$ and pepsin. Additionally, intestinal pinocytosis of polypeptides in the posterior intestine followed by intracellular digestion has been reported as a mechanism in different species to compensate for the absence of a stomach (Govoni et al. 1986, Ng et al. 2005, Zhang et al. 2016). In the case of $H$. ingens, the lack of pinocytotic vesicles in the posterior intestine may be due to the starvation condition of the studied individuals, which were not fed for at least $24 \mathrm{~h}$ before this study. All the enzymatic activities tested were present, indicating that $H$. ingens have a complete enzymatic spectrum to properly digest the major nutrients in their diet (i.e. protein, lipids, and carbohydrates) by the action of pancreatic enzymes secreted into the intestinal lumen (trypsin, chymotrypsin, amylase, and lipase, respectively). Additionally, the activity of enzymes found in the intestinal mucosa (acid and alkaline phosphatases, aminopeptidase) suggests the presence of fully functional enterocytes in the intestines. Indeed, acid and alkaline phosphatase has been associated with the maturation of the enterocytes of the digestive tract and the complete development of the absorptive function in the intestinal epithelium (He et al. 2012, Zacarías-Soto et al. 2013, Novelli et al. 2016).

Trypsin is an endopeptidase secreted from the pancreas into the intestine as an inactive form. It is activated by enterokinase in the intestine, and in turn, it is responsible for the activation of other digestive enzymes (Zambonino-Infante \& Cahu 2001). The trypsin activity in $H$. ingens was higher than the other protease enzymes analyzed (aminopeptidase and chymotrypsin). Also been reported in other seahorses like H. abdominalis (Wardley 2006) and H. guttulatus (Blanco et al. 2016) and many other teleost species before the presence of pepsin activity in the stomach when the acid proteolytic activity becomes the main mechanism for protein hydrolysis (Bitterlich 1985, Logothetis et al. 2001, He et al. 2012, MoguelHernández 2015). Chymotrypsin is another pancreatic protease secreted as an inactive form in the pancreas, and it is then activated by trypsin in the intestine. It has been proposed that chymotrypsin activity complements trypsin (Zambonino-Infante \& Cahu 2001). Its presence from early age coincides with the development of the functional pancreas (Rønnestad et al. 2013).

Additionally, the presence of chymotrypsin has been proposed as an indicator of the nutritional status and the growth capacity of fish (Cara et al. 2007). The levels of activity of trypsin may be related to the feeding habits of the seahorses, which are considered as visual opportunistic carnivorous predators, feeding on small animals like amphipods, copepods, mysids, and caridean shrimp (Woods 2003, Planas et al. 2017). Despite the absence of a stomach and the concomitant acid digestion, the alkaline proteolytic activity of the Pacific seahorse represented by trypsin and chymotrypsin suggests an efficient mechanism for protein digestion by this species. However, further studies are necessary to evaluate the effect of food quality and protein concentration on the proteolytic capacity of the juvenile Pacific seahorse.

The activity of aminopeptidase in $H$. ingens showed extremely low values and almost undetectable concerning the rest of the digestive enzymes analyzed. This low activity has been observed in some stomachless herbivorous and carnivorous fishes like the topsmelt silverside Atherinops affinis (Horn et al. 2006) and the Buffon's river-garfish Zenarchopterus buffonis (Zainal-Abidin et al. 2016), respectively. Aminopeptidase is an enzyme found in the microvilli membrane of intestinal cells. However, it has also been found in the cytoplasmic organelles and vesicles of epithelial cells. And it has been used as markers to differentiate enterocytes and their absorptive function (Gawlicka et al. 1995, Tengjaroenkul 2000, Cota-Mamani 2016). It has also been mentioned that an increase in this enzyme activity occurs with food in the digestive tract (MoguelHernández 2015). In this sense, the $H$. ingens specimens used in this study were starved for $24 \mathrm{~h}$ before the study, which could explain the low activity of aminopeptidase in their digestive tract. Additionally, the use of a homogenate of the digestive tract and not a dissected section of the intestinal mucosa may influence the result as reported in other studies (Zambonino-Infante \& Cahu 2001)

Lipase is one of the most important enzymes for lipid digestion and is reported in $H$. abdominalis (Wardley 2006). The high lipase activity in juveniles of $H$. ingens suggests a higher requirement of lipids during this developmental stage. Amylase is a carbohydrase secreted by the exocrine pancreas into the intestine, hydrolyzing alfa bounds in carbohydrates. Its presence is an indicator of the maturation of the pancreas (Blanco et al. 2016, Zainal-Abidin et al. 2016). In several fish species, it has been observed that amylase activity is high during the early stages of development, giving 
them the ability to digest carbohydrates; however, the activity decreases progressively as the fish develops into a juvenile (Zambonino-Infante \& Cahu 2001). In other species, the amylase activity increases towards the end of the larval period (Ma et al. 2005, Babaei et al. 2011). The detection of amylase in juvenile $H$. ingens showed that it could digest carbohydrates, though more studies are necessary to evaluate its variation during development.

In conclusion, juveniles of $H$. ingens present a welldeveloped digestive system. No stomach is present. In the anterior esophagus and the middle intestine, there is a greater presence of goblet cells of acidic type and higher villi, attributing them a lubricative and an immune function and a larger absorptive surface in the intestine. In the posterior esophagus and the posterior intestine, the thickness of the muscle suggests more active peristalsis. The enzymatic activity detected show that $H$. ingens has complete enzymatic machinery to digest the major nutrients in the food and the high-level lipase activity suggest a high lipid requirement by $H$. ingens. However, further research is needed to gain more knowledge regarding the digestive physiology and nutritional requirements during the development of H. ingens.

\section{ACKNOWLEDGMENTS}

The present study was supported by the institutional project SIP-IPN number 20171031. D.C.R. is a recipient of BEIFI-IPN and CONACYT Master fellowships. RP received fellowships from the Estímulo al Desempeño de los Investigadores (EDI; Performance Incentives) and the Comisión de Operación y Fomento de Actividades Académicas (COFAA; Commission for the Advancement of Academic Activities). The support of INGENS Cultivos Marinos by donating the juveniles is acknowledged.

\section{REFERENCES}

Al-Abdulhadi, H.A. 2005. Some comparative histological studies on alimentary tract of tilapia fish (Tilapia spilurus) and sea bream (Mylio cuvieri). Egyptian Journal of Aquatic Research, 31: 387-397.

Babaei, S.S., Kenari, A.A., Nazari, R. \& Gisbert, E. 2011. Developmental changes of digestive enzymes in Persian sturgeon (Acipenser persicus) during larval ontogeny. Aquaculture, 318: 138-144. doi: 10.1016/ j.aquaculture.2011.04.032

Banan-Khojasteh, S.M., Sheikhzadeh, F., Mohammadnejad, D. \& Azami, A. 2009. Histological, histochemical and ultrastructural study of the intestine of rainbow trout
(Oncorhynchus mykiss). World Applied Sciences Journal, 6: 1525-1531.

Bitterlich, G. 1985. Digestive enzyme pattern of two stomachless filter feeders, silver carp, Hypophthalmichthys molitvix Val., and bighead carp, Avistichthys nobilis Rich. Journal of Fish Biology, 27: 103-112. doi: 10.1111/j.1095-8649.1985.tb04013.x

Blanco, A., Planas, M. \& Moyano, F.J. 2016. Ontogeny of digestive enzymatic capacities in juvenile seahorses Hippocampus guttulatus fed on different live diets. Aquaculture Research, 47: 3558-3569. doi: 10.1111/ are. 12806

Bradford, M.M. 1976. A rapid and sensitive method for quantitation of microgram quantities of proteins utilizing the principle of protein-dye binding. Analytical Biochemistry, 72: 248-254. doi: 10.1016/00032697(76)90527-3

Cara, B., Moyano, F.J., Zambonino, J.L. \& Fauvel, C. 2007. Trypsin and chymotrypsin as indicators of nutritional status of post-weaned sea bass larvae. Journal of Fish Biology, 70: 1798-1808. doi: 10.1111/ j.1095-8649.2007.01457.x

Cardoso, N.N., Firmiano, E.M.S., Gomes, I.D., Nascimiento, A.A., Sales, A. \& Araújo, F.G. 2015. Histochemical and immunohistochemical study on endocrine cells (5HT, GAS, and SST) of the gastrointestinal tract of a teleost, the characin Astyanax bimaculatus. Acta Histochemica, 117: 595-604. doi: 10.1016/j.acthis.2015.05.007

Carrassón, M., Grau, A., Dopazo, L.R. \& Crespo, S. 2006. A histological, histochemical and ultrastructural study of the digestive tract of Dentex dentex (Pisces, Sparidae). Histology and Histopathology, 21: 579593. doi: 10.14670/HH-21.579

Chen, B.N., Qin, J.G., Kumar, M.S., Hutchison, W. \& Clarke, S. 2006. Ontogenetic development of the digestive system in yellowtail kingfish Seriola lalandi larvae. Aquaculture, 256: 489-501. doi: 10.1016/j. aquaculture.2006.01.041

Çinar, K. \& Şenol, N. 2006. Histological and histochemical characterization of the mucosa of the digestive tract in flower fish (Pseudophoxınus antalyae). Anatomia, Histologia, Embryologia, 35: 147-151. doi: 10.1111/j.1439-0264.2005.00629.x

Cohen, S., Díaz, M.V. \& Díaz, A.O. 2013. Histological and histochemical study of the digestive system of the Argentine anchovy larvae (Engraulis anchoita) at different developmental stages of their ontogenetic development. Acta Zoologica, 95: 409-420. doi: 10.1111/azo.12038

Cota-Mamani, N.J. 2016. Ontogenia del sistema digestivo y caracterización de la actividad enzimática de las 
larvas de chita Anisotremus scapularis (Tschudi, 1846). Master Thesis, Centro de Investigación Científica y de Educación Superior de Ensenada, Ensenada.

Corona-Rojas, D.A. 2015. Descripción histológica de juveniles del caballito del Pacífico (Hippocampus ingens) Girard, 1858. Graduate Thesis, Universidad Autónoma de Baja California Sur B.C.S., México.

Corona-Rojas, D.A. 2018. Estructura histológica, características histoquímicas y actividad enzimática del tubo digestivo del caballito del Pacífico Hippocampus ingens (Girard, 1858). Master Thesis, Centro Interdisciplinario de Ciencias Marinas, Ciudad de México.

Dos-Santos, M.L., Arantes, F.P., Santiago, K.B. \& DosSantos, J.E. 2015. Morphological characteristics of the digestive tract of Schizodon knerii (Steindachner, 1875), (Characiformes: Anostomidae): an anatomical, histological and histochemical study. Annals of the Brazilian Academy of Sciences, 87: 867-878. doi: 10.1590/0001-3765201520140230

Domeneghini, C., Pannelli-Straini, R. \& Veggetti, A. 1998. Gut glycoconjugates in Sparus aurata L. (Pisces, Teleostei). A comparative histochemical study in larval and adult stages. Histology and Histopathology, 13: 359-372. doi: 10.14670/HH-13.359

Foster, S.J. \& Vincent, A.C. 2004. Life history and ecology of seahorses: implications for conservation and management. Journal of Fish Biology, 65: 1-61. doi: 10.1111/j.0022-1112.2004. 00429.x

Gawlicka, A., Teh, S.J., Hung, S.S.O., Hinton, D.E. \& De la Noüe, J. 1995. Histological and histochemical changes in the digestive tract of white sturgeon larvae during ontogeny. Fish Physiology and Biochemistry, 14: 357-371. doi: 10.1007/BF00003374

Gisbert., S., Morais, S. \& Moyano, F.J. 2013. Feeding and digestion. In: Qin, J.G. (Ed.). Larval fish aquaculture. Nova Science Publishers, New York, pp. 73-123.

Gisbert, E., Piedrahita, R.H. \& Conklin, D.E. 2004. Ontogenetic development of digestive system in California halibut (Paralichthys californicus) with notes on feeding practices. Aquaculture, 232: 455-470. doi: 10.1016/S0044-8486(03)00457-5

Gómez-Ramírez, E., Tovar-Bohorquez, M.O., ObandoBulla, M.J. \& Hurtado-Giraldo, H. 2010. Estudio histológico del tracto digestivo del pez Ariopsis seemanni (Ariida). Revista Facultad de Ciencias Básicas, 6: 216-225. doi: 10.18359/rfcb.2075

Govoni, J.J., Boehlert, G.W. \& Watanabe, Y. 1986. The physiology of digestion in fish larvae. Environmental Biology of Fishes, 16: 56-77. doi: 10.1007/BF0 0005160
Guzmán-Beltran, L., Santana, D., Verdugo, H., GómezRamírez, E. \& Hurtado-Giraldo, H. 2013. Descripción anatómica e histológica del tracto digestivo de nicuro Pimelodus blochii (Valenciennes, 1840). Orinoqua, 17: 102-110. doi: 10.22579/20112629.55

He, T., Xiao, Z., Liu, Q., Ma, D., Xu, S., Xiao, Y. \& Li, J. 2012. Ontogeny of the digestive tract and enzymes in rock bream Oplegnathus fasciatus (Temminck et Schlegel 1844) larvae. Fish Physiology and Biochemistry, 38: 297-308. doi: 10.1007/s10695-0119507-y

Hernández, D.R., Santinón, J.J., Sánchez, S. \& Domitrovic, H.A. 2014. Estudio histológico e histoquímico de la organogénesis del tubo digestivo de Rhamdia quelen en condiciones de larvicultura intensiva. Latin American Journal of Aquatic Research, 42: 1136-1147. doi: 10.3856/vol42-issue5fulltext-17

Horn, M.H., Gawlicka, A.K., German, D.P., Logothetis, E.A., Cavanagh, J.W. \& Boyle, K.S. 2006. Structure and function of the stomachless digestive system in three related species of new world silverside fishes (Atherinopsidae) representing herbivory, omnivory, and carnivory. Marine Biology, 149: 1237-1245. doi: 10.1007/s00227-006-0281-9

Koldewey, H.J. \& Martin-Smith, K.M. 2010. A global review of seahorse aquaculture. Aquaculture, 302: 131-152. doi: 10.1016/j.aquaculture.2009.11.010

Logothetis, E.A., Horn, M.H. \& Dickson, K.A. 2001. Gut morphology and function in Atherinops affinis (Teleostei: Atherinopsidae), a stomachless omnivore feeding on macroalgae. Journal of Fish Biology, 59: 1298-1312. doi: 10.1111/j.1095-8649.2001.tb00193.x

Lourie, S.A., Foster, S.J., Cooper, E.W.T. \& Vincent, A.C.J. 2004. A guide to the identification of seahorses. University of British Columbia and World Wildlife Fund, Washington, DC.

Ma, H.M., Cahu, C. \& Zamnonino-Infante, J.L. 2005. Activities of selected digestive enzymes during larval development of large yellow croaker (Pseudosciaena crocea). Aquaculture, 245: 239-248. doi: 10.1016/j. aquaculture.2004.11.032

Mai, K., Yui, H., Ma, H., Duan, Q., Gisbert, E., Zambonino-Infante, J.L. \& Cahu, C. 2005. A histological study on the development of the digestive system of Pseudosciaena crocea larvae and juveniles. Journal of Fish Biology, 67: 1094-1106. doi: 10.1111/ j.0022-1112.2005.00812.x

Manjakasy, J.M., Day, R.D., Kemp, A. \& Tibbetts, I.R. 2009. Functional morphology of digestion in the stomachless, piscivorous needlefishes Tylosurus gavialoides and Strongylura leiura ferox (Teleostei: 
Beloniformes). Journal of Morphology, 270: 11551165. doi: 10.1002/jmor. 10745

Maraux, S., Louvard, D. \& Baratti, J. 1973. The aminopeptidase from hog-intestinal brush border. Biochimica et Biophysica Acta, 321: 282-295. doi: 10.1016/0005-2744(73)90083-1

Moguel-Hernández, I. 2015. Fisiología digestiva durante el desarrollo larval del pargo lunarejo Lutjanus guttatus. Ph.D. Thesis, Instituto Politécnico NacionalCICIMAR-IPN, Ciudad de México.

Murray, H.M., Wright, G.M. \& Goff, G.P. 1996. A comparative histological and histochemical study of the post-gastric alimentary canal form three species of pleuronectid, the Atlantic halibut, the yellowtail flounder and the winter flounder. Journal of Fish Biology, 48: 187-206. doi: 10.1111 j.1095-8649.1996. tb01112.x

Nazlić, M., Paladin, A. \& Bočina, I. 2014. Histology of the digestive system of the black scorpionfish Scorpaena porcus L. Acta Adriatica, 55: 65-74.

Neuhaus, M., Van Der Marel, N., Caspari, W., Meyer, M., Enss, L. \& Steinhagen, D. 2007. Biochemical and histochemical study on the intestinal mucosa of the common carp Cyprinus carpio L., with special consideration of mucin glycoproteins. Journal of Fish Biology, 70: 1523-1534. doi: 10.1111/j.1095-8649. 2007.01438.x

Ng, A.N.Y., De Jong-Curtain, T.A., Mawdsley, D.J., White, S.J., Shin, J., Appel, B., et al. 2005. Formation of the digestive system in zebrafish: III. Intestinal epithelium morphogenesis. Developmental Biology, 286: 114-135. doi: 10.1016/j.ydbio.2005.07.013

Novelli, B., Otero-Ferrer, F., Díaz, M., Socorro, J.A., Caballero, M.J., Molina-Domínguez, L. \& Moyano, F.J. 2016. Digestive biochemistry as indicator of the nutritional status during early development of the long-snouted seahorse (Hippocampus reidi). Aquaculture, 464: 196-204. doi: 10.1016/j.aquaculture.2016. 06.037

Novelli, B., Socorro, J.A., Caballero, M.J., Otero-Ferrer, F., Segade-Botella, A. \& Molina-Domínguez, L. 2015. Development of seahorse (Hippocampus reidi, Ginsburg 1933): histological and histochemical study. Fish Physiology and Biochemistry, 41: 1233-1251. doi: 10.1007/s10695-015-0082-5

Ofelio, C., Díaz, A.O., Radaelli, G. \& Planas, M. 2018. Histological development of the long-snouted seahorse Hippocampus guttulatus during ontogeny. Journal of Fish Biology, 93: 72-87. doi: 10.1007 /s10695-015-0082-510.1111/jfb.13668

Otero-Ferrer, F. 2011. Seahorses in Gran Canaria Island (Spain): ecology and aquaculture. Combined tools for marine conservation issues. Ph.D. Thesis, Universidad de las Palmas de Gran Canaria, Las Palmas.
Palma, J., Bureau, D.P. \& Andrade, J.P. 2014. The effect of diet on ontogenic development of the digestive tract in juvenile reared long snout seahorse Hippocampus guttulatus. Fish Physiology and Biochemistry, 40: 739-750. doi: 10.1007/s10695-013-9881-8

Pearse, A.G.E. 1985. Histochemistry, theoretical and applied. Vol. 2. Analytical technology. Churchill Livingstone, New York.

Planas, M., Burhans, R. \& Simões, N. 2017. Seahorses and pipefish. In: Calado, R., Olivotto, I., Planas, M. \& Holt, J. (Eds.). Marine ornamental species aquaculture. John Wiley \& Sons, New Jersey, pp. 299-383.

Ribeiro, L., Sarasquete, C. \& Dinis, M.T. 1999. Histological and histochemical development of the digestive system of Solea senegalensis (Kaup, 1858) larvae. Aquaculture, 171: 293-308. doi: 10.1016/S00 44-8486(98)00496-7

Rønnestad, I., Yúfera, M., Ueberschär, B., Ribeiro, L., Sæle, Ø. \& Boblione, C. 2013. Feeding behavior and digestive physiology in larval fish: current knowledge, gaps and bottlenecks in research. Reviews in Aquaculture, 5: 59-98. doi: 1111/raq.12010

Rotllant, G., Moyano, F.J., Andrés, M., Díaz, M., Estévez, A. \& Gisbert, E. 2008. Evaluation of fluorogenic substrates in the assessment of digestive enzymes in a decapod crustacean Maja brachydactyla larvae. Aquaculture, 282: 90-96. doi: 10.1016/j.aquaculture. 2008.06.004

Sarasquete, M.C., Gisbert, E., Ribeiro, L., Vieira, L. \& Dinis, M.T. 2001. Glycoconjugates in epidermal, branchial and digestive mucous cells in gastric glands of gilthead sea bream Sparus aurata, Senegalese sole, Solea senegalensis and Siberian sturgeon, Acipenser baeri development. European Journal of Histochemistry, 45: 267-278. doi: 10.4081/1637

Sarasquete, M.C., Polo, A. \& Yúfera, M. 1995. Histology and histochemistry of the development of the digestive system of larval gilthead seabream, Sparus aurata L. Aquaculture, 130: 79-92. doi: 10.1016/0044-8486(94) 00175-N

Segade, Á., Robaina, L., Novelli, B., Otero-Ferrer, F. \& Molina-Domínguez, L. 2016. Effect of the diet on lipid composition and liver histology of short snout seahorse Hippocampus hippocampus. Aquaculture Nutrition, 22: 1312-1319. doi: 10.1111/anu.12341

Shi, G., Wang, J.X., Liu, X.Z. \& Wang, R.X. 2007. Study on histology and histochemistry of digestive tract in Sebastiscus marmoratus. Journal of Fisheries of China, 31: 293-302.

Teles, A., Salas-Leiva, J., Alvarez-González, C.A., Gisbert, E., Ibarra-Castro, L., Urbiola, J.C.P. \& TovarRamírez, D. 2017. Histological study of the gastrointestinal tract in longfin yellowtail (Seriola rivoliana) 
larvae. Fish Physiology and Biochemistry, 43: 16131628. doi: 10.1007/ s10695-017-0397-5

Tengjaroenkul, B. 2000. Ontogenic morphology and enzyme activities of the intestinal tract of the Nile tilapia, Oreochromis niloticus. Ph.D. Thesis, Virginia Polytechnic Institute and State University, Virginia.

Toledo-Cuevas, E.M., Moyano-López, F.J., TovarRamírez, D., Strüssmann, C.A., Álvarez-González, C.A., Martínez-Chávez, C.C. \& Martínez-Palacios, C.A. 2011. Development of digestive biochemistry in the initial stages of three cultured Atheriopsids. Aquaculture Research, 42: 776-786. doi: 10.1111/j. 1365-2109.2011.02853.x

Vega-Villasante, F., Nolasco, H. \& Civera, R. 1993. The digestive enzymes of the Pacific brown shrimp Penaeus californiensis. I. Properties of amylase activity in the digestive tract. Comparative Biochemistry and Physiology - Part B: Biochemistry and Molecular Biology, 106: 547-550. doi: 10.1016/03050491(93)90130-W

Vieira-Lopes, D.A., Pinheiro, N.L., Sales, A., Ventura, A., Araújo, F.G., Gomes, I.D. \& Nascimento, A.A. 2013. Immunohistochemical study of the digestive tract of Oligosarcus hepsetus. World Journal of Gastroenterology, 19: 1919-1929. doi: 10.3748/wjg.v19.i12. 1919

Wardley, T.R. 2006. A study on the feeding of the potbellied seahorse (Hippocampus abdominalis): reducing the reliance on brine shrimp (Artemia). Ph.D. Thesis, University of Tasmania, Launceston.

Wegner, A., Ostaszewska, T. \& Rożek, W. 2009. The ontogenetic development of the digestive tract and accessory glands of sterlet (Acipenser ruthenus L.) larvae during endogenous feeding. Reviews in Fish Biology and Fisheries, 19: 431-444. doi: 10.1007/ s11160-009-9111-8

Wilson, J.M. \& Castro, L.F.C. 2011. Morphological diversity of the gastrointestinal tract in fishes. In: Martin, G., Farrell, A.P. \& Brauner, C.J. (Eds.). The multifunctional gut of fish. Academic Press, London, pp. 1-55.
Wołczuk, K., Nowakowska, J., Płąchocki, D. \& Kakareko, D. 2014. Histological, histochemical, and ultrastructural analysis reveals functional division of the oesophagogastric segment in freshwater tubenose goby Proterorhinus semilunaris Heckel, 1837. Zoomorphology, 134: 259-268. doi: 10.1007/s00435014-0250-7.

Woods, C.M.C. 2003. Growth and survival of juvenile seahorse Hippocampus abdominalis reared on live, frozen and artificial foods. Aquaculture, 220: 287-298. doi: 10.1016/S0044-8486(02)00227-2

Yang, R., Xie, C., Fan, Q., Gao, C. \& Fang, L. 2010. Ontogeny of the digestive tract in yellow catfish Pelteobagrus fulvidraco larvae. Aquaculture, 302: 112-123. doi: 10.1016/j.aquaculture. 2010.02.020

Zacarías-Soto, M., Barón-Sevilla, B. \& Lazo, J.P. 2013. Ontogeny and distribution of alkaline and acid phosphatases in the digestive system of California halibut larvae (Paralichthys californicus). Fish Physiology and Biochemistry, 39: 1331-1339. doi: 10.1007/s10695-013-9787-5

Zainal-Abidin, D.A., Hashim, M., Das, S.K., Rahim, S.M. \& Ghaffar-Mazlan, A. 2016. Enzymatic digestion of stomachless fish Zenarchopterus buffonis. AACL Bioflux, 9: 695-703.

Zambonino-Infante, J.L. \& Cahu, C. 2001. Ontogeny of the gastrointestinal tract of marine fish larvae. Comparative Biochemistry and Physiology - Part C: Toxicology \& Pharmacology, 130: 477-487. doi: 10.1016/S1532-0456 (01)00274-5

Zambonino-Infante, J.L., Gisbert, E., Sarasquete, C., Navarro, I., Gutiérrez, J. \& Cahu, C. 2008. Ontogeny and physiology of the digestive system of marine fish larvae. In: Cyprino, J.E.P., Bureau, D.P. \& Kapoor, B.G. (Eds.). Feeding and digestive functions of fishes. CRC Press, Boca Raton, pp. 281-348.

Zhang, J., Yang, R., Yang, X., Fan, Q., Wei, K. \& Wang, W. 2016. Ontogeny of the digestive tract in mud loach Misgurnus anguillicaudatus larvae. Aquaculture Research, 47: 1180-1190. doi: 10.1111/are.12574 